\title{
«Escuelas de democracia»: el tajo y la parroquia como espacios cotidianos de conflictividad durante el franquismo final en el campo altoandaluz
}

\author{
GLORIA ROMÁN RUIZ
}

\begin{abstract}
PALABRAS CLAVE: conflictividad, democratización, mundo rural, tardofranquismo.
\end{abstract}

CÓdIGOS JEL: D63, D71, D74, J52.

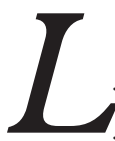

os habitantes del mundo rural, a los que tradicionalmente se han atribuido mayores cotas de consentimiento hacia la dictadura franquista (1939-1975) y mayores índices de apatía política, no permanecieron siempre ni mayoritariamente pasivos. El objetivo de este artículo es desmitificar y revalorizar el papel jugado por el campo en el proceso de democratización de las décadas de los sesenta y setenta, etapa en la que se detectan numerosos sintomas del deterioro de la relación entre el Estado y la sociedad civil. El texto atiende a los episodios de conflictividad en dos de los ámbitos más dinámicos del agro durante el periodo, el laboral y el eclesiástico. La tesis defendida es que, en la articulación de la protesta, la sociedad rural experimentó un proceso de aprendizaje de cultura democrática. La investigación se vale de fuentes variadas como las cartas remitidas desde distintos pueblos de Andalucía oriental o Alta Andalucía (que engloba las provincias de faén, Málaga, Granada y Almería) a la emisora clandestina del Partido Comunista en el exilio, La Pirenaica, disponibles hoy en el AHPCE. Asimismo, recurre a los partes de actividades del clero de las diócesis altoandaluzas, generados por el gabinete de enlace del Ministerio de Información y Turismo, y a las memorias anuales de los gobernadores civiles, ambos conservados en el $A G A$. 


\section{"Schools of democracy" the workplace and the parish as everyday spaces of conflictivity during the late francoism in rural andalusia}

\section{KEYWORDS: conflictivity, democratization, rural world, late Fran- coism.}

\section{JEL CODES: D63, D71, D74, J52.}

nhabitants of the rural world in Spain have generally been attributed higher lev-
els of political apathy and acquiescence towards the Francoist dictatorship (1939-
1975); but they did not always, nor did most of them, remain passive. The objective of this article is to demystify and reassess the role of the rural world in democratization processes of the 1960s and 1970s in Spain, a period of deterioration in the relationship between the state and the civil society. By looking at episodes of conflict in two of the most dynamic spheres of rural life at that time, the workplace and the Church, we argue that rural society engaged in a democratic learning process through the articulation of protest. The research relies on diverse sources such as letters from people in several eastern Andalusian towns in the provinces of faén, Málaga, Granada and Almeria along with records from the clandestine Communist Party radio station La Pirenaica, which are available in the AHPCE. We also include the activity reports of clergy from Andalusian dioceses, generated by the Ministry of Information and Tourism, and the annual reports of Civil Governors, both of which are conserved in the state archives $(A G A)$.

Gloria Román Ruiz [orcid.org/0000-0003-4102-3076] es doctora en Historia Contemporánea por la Universidad de Granada. Dirección para correspondencia: Departamento de Historia Contemporánea, Facultad de Filosofía y Letras, Campus Universitario de Cartuja, 18071 Granada (España).C.e.: gloriaroman@ugr.es 


\section{LA CONSTRUCCIÓN DE LA DEMOCRACIA EN EL CAMPO}

\section{Aqui se odia a Franco y todas sus canalladas, lo que queremos es libertad [...] La gente quiere libertad, democracia, y no payasadas franquistas ${ }^{1}$.}

A la hora de abordar el fenómeno de la democratización durante los últimos años del franquismo (1939-1975) y primeros de la transición (1975-1982), la historiografía especializada de la última década ha renovado el enfoque en cuanto a la cronología del proceso, los ámbitos en que aconteció y los actores protagonistas. Respecto del marco temporal, actualmente se asume que es posible rastrear un temprano cambio de mentalidad con anterioridad al «boom económico» y al cambio político-institucional, incluso ya desde finales de los cincuenta. Este planteamiento supone, de un lado, aceptar que es posible el inicio de la democratización bajo un régimen político no democrático. De otro lado, esta asunción entra en contradicción con los presupuestos sostenidos por la ya obsoleta teoría de la modernización que, al establecer una relación mecánica entre desarrollo económico y democratización, no resulta válida para aquellas regiones escasamente industrializadas, además de restar todo el protagonismo a la sociedad civil. Por su parte, la conclusión del proceso democratizador no podría fijarse en diciembre de 1978, cuando se aprobó la Constitución, sino tiempo después ${ }^{2}$. El proceso de democratización en el mundo rural tuvo sus hitos particulares, caso de la celebración de las primeras elecciones a cámaras agrarias en 1978 o de las primeras elecciones municipales en 1979, que supusieron la democratización de los ayuntamientos ${ }^{3}$.

En cuanto al marco espacial, se ha abogado por análisis multiescalares a nivel local, provincial y nacional. La descentralización del estudio de la democratización ha permitido poner el foco sobre las regiones periféricas nula o escasamente industrializadas donde nada [amenazante] parecía ocurrir ${ }^{4}$. Esta nueva perspectiva ha posibilitado integrar en el análisis al mundo rural, donde tradicionalmente más se han subestimado las prácticas políticas $^{5}$. Es cierto que los ecos de cuanto sucedía en las principales ciudades del país y

1. Archivo Histórico del Partido Comunista de España (AHPCE), REI, 191a/1, Almería, 14/12/1965.

2. Bernecker (2007: 67, 69); RAdCliff (2011: 2); Herrera (2011: 166); Ortiz (2016: 32, 4142). La idea de que la Transición comenzó mucho antes de la muerte de Franco es defendida también en YSÀs (2006). Para una revisión de la teoria de la modernización, véase INGLEHART y WELZEL (2009).

3. Las elecciones a cámaras agrarias han sido interpretadas como un ensayo de las elecciones municipales en HERRERA (2009: 233-239).

4. MARTín (2008: 29).

5. Algunos ejemplos en los que se atiende al mundo rural: Nicolás (2007: 251-267); MARTíN 
en las capitales de provincia llegaban hasta los pueblos andaluces, pero no lo es menos que a menudo el ámbito rural tuvo dinámicas autónomas. Pese al gran peso que tuvo en la España del siglo xx, el mundo agrario ha estado frecuentemente disociado de los procesos democratizadores, considerado más permeable a la ideología franquista y vinculado con actitudes inmovilistas. Al contrario, el ámbito urbano ha sido tenido por más politizado y proclive a la articulación de comportamientos contestatarios susceptibles de poner a la dictadura contra las cuerdas. En consecuencia, el campo ha merecido a los historiadores de la democratización menos atención que la ciudad ${ }^{6}$. Sin embargo, la existencia de importantes sectores del agro desmovilizados no implica necesariamente que el apoyo al régimen franquista fuese mayoritario en este ámbito, pues el marco dictatorial en que se movían estos hombres y mujeres acrecentaba los costes de participación ${ }^{7}$. Además, el que las actitudes apáticas estuvieran extendidas no excluye ni contradice la aparición de importantes cotas de conflictividad y micromovilización ${ }^{8}$.

En lo referente a los actores protagonistas del proceso democratizador, las nuevas perspectivas historiográficas están tendiendo a integrar en el análisis a colectivos que llevaron a cabo iniciativas aparentemente insignificantes, pero en realidad dotadas de gran valor a la hora de extender actitudes cívicas en sus respectivas comunidades. Estos nuevos debates a los que nos adscribimos reconocen el protagonismo compartido entre las élites políticas y la sociedad civil, admitiendo la pluralidad de actores intervinientes en el proceso transicional ${ }^{9}$. Es cierto que la existencia bajo el franquismo de la sociedad civil, entendida como el ámbito social que escapa al control estatal, ha sido puesta en entredicho. Sin embargo, como explicara Víctor Pérez Díaz, aunque no estaba plenamente desarrollada, había comenzado ya a despegar para cuando comenzó la democratización ${ }^{10}$.

Entre los agentes democratizadores insuficientemente atendidos, y a los que sí presta atención este artículo, estuvieron los emigrantes retornados o los párrocos rurales. Estos sujetos políticos asumieron un rol muy significativo en muchas de las movilizaciones del periodo, así como en el proceso de construcción de poderes civiles alternativos a los de la dictadura. Aunque no todos ellos compartían una visión idéntica acerca del ideal de

(2016). Entre los trabajos desmitificadores: HERRERA et al. (2012); HERRERA y MARKoff (2013); LANERO y MíGuez MACHO (2013).

6. Como ponía recientemente de manifiesto SANZ (2017), aún queda mucho por conocer acerca de las formas contestatarias en el mundo rural.

7. Así lo han puesto de manifiesto trabajos como Cobo y ORTEga (2003), FerRer (2014) y FerNÁNDEZ AMADOR y Quirosa-Cheyrouze (2017).

8. Sevillano (2000: 212). Sobre la coexistencia de pasividad y conflictividad, véase Ysás (2007).

9. GonZÁlez MADrid y MARTíN (2009).

10. Pérez Díaz (1993: 58, 78). 
democracia, sí eran partidarios de una relación más igualitaria con el Estado, así como de una creciente participación en la vida pública. Como explicara Foweraker, se trata de descender a ras de suelo, donde la gente aparece como individualidades concretas o al menos como actores sociales diferenciados con características especiales, para traerlos $d e$ vuelta a la democracia ${ }^{11}$.

Además, los nuevos análisis sobre el proceso de reconstrucción de la cultura ciudadana en España abogan por una explicación multicausal. Así, hemos de considerar la memoria de la cultura política de la Segunda República, aunque a menudo vaga y lejana, o la objetiva mejora de las condiciones materiales de vida desde finales de los cincuenta; pero también la debilidad de una dictadura forzada a abrir nuevos espacios de sociabilidad y a intensificar la represión; el papel de concienciación desempeñado por la oposición política y sindical; el carácter propicio del contexto internacional; o el «desenganche» de la Iglesia católica tras el Concilio Vaticano II (1962-1965). Asimismo, habremos de valorar positivamente, como haremos en las siguientes páginas, la movilización social y el «aprendizaje de cultura democrática» experimentado por los hombres y mujeres de a pie en los espacios de su propia cotidianeidad.

Durante los últimos años de la dictadura muchos habitantes del mundo rural tuvieron sus primeros contactos con la cultura prodemocrática (o favorable a la democratización) en sus ámbitos primarios de socialización cotidiana, aquellos que les resultaban más próximos y accesibles. Estos espacios se convirtieron en "escuelas de democracia» en las que tenían lugar reuniones y debates donde se producían intercambios de sensibilidades y experiencias comunes, como explicó María Candelaria Fuentes con relación a las asambleas del Partido Comunista de España (PCE) en el campo andaluz ${ }^{12}$. En ocasiones se trataba de viejos espacios de sociabilidad tradicional que durante el tardofranquismo adquirieron un nuevo significado, caso de muchas aulas escolares, parroquias o salones parroquiales. Otras veces se trató de nuevos espacios surgidos al calor de la vorágine de cambios de los años sesenta, como los centros o clubes culturales. Aunque cada uno de estos contextos de micromovilización (educativo, religioso y cultural) presentase rasgos y especificidades propias, constituían una red en la que operaban prácticas y lenguajes similares y en la que se compartía el objetivo común de avanzar hacia la democratización ${ }^{13}$.

11. FOWERAKER (1989: 3).

12. FUENTES (2012: 10).

13. El concepto en McAdAM (1988). 
En las luchas puestas en marcha en estos espacios de libertad ${ }^{14}$ los hombres y mujeres del agro andaluz comenzaron a familiarizarse con la cultura democrática, adquiriendo pautas y valores cívicos. Y es que las acciones de protesta activadas en estas «escuelas de democracia» no eran estrictamente laborales o culturales, sino que tenían un importante poso político, de ahí que el régimen franquista las persiguiera con vehemencia. Aunque estos episodios de conflicto fueron incapaces de evitar que el dictador muriese en la cama, tuvieron importantes implicaciones al contribuir al surgimiento de una cultura crítica y aumentar la presión sobre las élites políticas ${ }^{15}$. Como explicaba un socio del Centro Cultural de Estepona (Málaga) en 1977, cada vez estaba más extendida entre la población la convicción de que la resolución de sus problemas cotidianos pasaba necesariamente por la democratización del sistema:

\begin{abstract}
Para los enemigos del movimiento ciudadano el mayor peligro no es que los vecinos luchen por un problema concreto -por ejemplo, el precio del pan o el servicio telefónico-, sino que descubran que la raiz de muchos problemas aparentemente distintos es la misma: la existencia de un sistema en el que los intereses del pueblo cuentan menos que los de unos pocos. El descubrimiento de esta realidad convertirá a ciudadanos corrientes en hombres políticos ${ }^{16}$.
\end{abstract}

La adopción de estos nuevos enfoques ha llevado aparejada la asunción de una amplia noción de politización. La que manejamos en este artículo es lo suficientemente extensa para englobar prácticas cotidianas, en ocasiones sutiles y simbólicas, que van más allá de la militancia en una organización política o sindical y de las espectaculares acciones de protesta urbanas. Estrechamente relacionada aparece la noción de democratización, que -siguiendo a Tilly-hace referencia al movimiento neto hacia una consulta más mutuamente vinculante, más protegida, más igual y más amplia entre el Estado y la sociedad civil. Según éste y otros autores como Eley, la llegada de la democracia requiere siempre de la movilización popular o, en otras palabras, la ciudadanía no se concede o confiere, sino que se conquista. También Markoff ha subrayado la estrecha relación entre movilización social y democratización. Por su parte, Herrera prefiere hablar de construcción de la democracia en lugar de conquista para no caer en la idea de que es algo preexistente. En esta misma línea, Cenarro explica que la ciudadanía ha de ser entendida

14. El concepto, utilizado por primera vez en 1979 por Sara Evans, es analizado en Polleta (1999).

15. GROves et al. (2017a).

16. Hormigo (1977). 
no sólo como un estatus jurídico otorgado «desde arriba», sino como una práctica que conlleva un proceso de aprendizaje en el espacio público y que favorece la emergencia de nuevos hábitos, un lenguaje de derechos y una reformulación identitaria colectiva basada en la idea de pertenencia a una "comunidad imaginada» ${ }^{17}$.

\section{EL TAJO: LA CONFLICTIVIDAD EN EL ÁMBITO LABORAL}

Campesinos de la provincia de faén, trabajadores de todas las profesiones, unirse todos sin distinción de ideas u opiniones, socialistas, comunistas, anarquistas, católicos, republicanos, sindicalistas de todas las tendencias, hombres y mujeres que deseen vivir dentro de un orden democrático y de libertad en el concierto internacional [...]. Unirse todos por que la huelga política sea un hecho histórico en nuestras luchas contra Franco por la libertad y la democracia en España ${ }^{18}$.

$\mathrm{Al}$ inaugurar la década de los sesenta, el mundo rural estaba inmerso en un proceso de importantes transformaciones socioeconómicas. Desde mediados de los cincuenta la sociedad agraria tradicional atravesaba una profunda crisis motivada por la creciente mecanización de las faenas agrícolas y por el consiguiente éxodo rural ${ }^{19}$. Del primer fenómeno da buena cuenta el hecho de que en 1962 hubiese ya censados en las provincias altoandaluzas 3.849 tractores, número que en los siguientes años no haría más que aumentar ${ }^{20}$. Respecto de la migración interior, solo en 1964 salieron de Andalucía oriental 54.803 personas con rumbo a las regiones más industrializadas del país. A estos emigrantes habría que sumar aquellos que marcharon al extranjero, que -según datos oficiales (que, por tanto, no contemplan a los no asistidos por el Instituto Español de Emigración)- ascendían a $11.046^{21}$. Se calcula que en el periodo comprendido entre 1950 y 1970 Andalucía perdió hasta 1,4 millones de habitantes ${ }^{22}$. Según un trabajador granadino que escribió una carta a La Pirenaica en el verano de 1963, decenas de miles de personas de la provincia vivían de los giros que los hijos o el marido envía cada mes

17. Tilly (2010: 45, 93, 113); Eley (2003); Herrera (2009: 221); Markoff (2018); Cenarro (2016: 13-21, 14).

18. Fragmento de la carta escrita por un trabajador jiennense a La Pirenaica. AHPCE, REI, 175/6, Jaén, 13/08/1963.

19. Abad y NARedo (1997); OrTega (2003: 226-231).

20. INE, Censo Agrario 1962. «Motores y tractores de uso en las explotaciones».

21. INE, Anuario 1965. «Emigrantes, según provincias de procedencia» $\mathrm{y}$ «Emigrantes asistidos por el Instituto Español de Emigración».

22. García Barbancho (1975); Zambrana (2002: 97). 
desde el extranjero. De profunda pena ver las colas de mujeres en Correos para cobrar el giro $^{23}$.

Uno de los municipios andaluces más afectados por la emigración fue Teba (Málaga), donde existía una importante presencia del latifundio (un 13,4\% de las explotaciones pasaban de las 30 hectáreas y entre solo cuatro fincas ocupaban hasta 3.616 hectáreas de superficie, además de que el régimen mayoritario de tenencia de la tierra era el arrendamiento, que representaba más del $58 \%)^{24}$ y, consecuentemente, una amplia masa de jornaleros. Desde principios de los cincuenta comenzaron a salir de esta localidad familias enteras que marchaban a trabajar temporalmente a Francia o ponían rumbo a Barcelona o Baracaldo (Vizcaya), movidas por la falta de trabajo y de viviendas en buenas condiciones de habitabilidad. Estos desplazamientos ocasionaron un drástico descenso de la población de hecho del municipio, que pasó de contar con 7.231 habitantes en 1951 a tener tan solo 6.003 en 1969. La pérdida demográfica continuó en los años siguientes, y el número de sus habitantes se redujo a 5.243 en el año $1973^{25}$. Uno de aquellos emigrantes tebeños fue Juan Jiménez, hijo de un republicano ejecutado durante la Guerra Civil, que emigró a Bilbao en 1961 harto del campo ${ }^{26}$.

A menudo quienes habían emprendido el periplo migratorio regresaban al pueblo con motivo de las fiestas patronales o durante las vacaciones de verano. Además, desde finales de los sesenta y principios de los setenta muchos comenzaron a retornar a su lugar de origen con carácter definitivo. En aquellos regresos a la patria chica los migrantes, que se habían familiarizado con el clima de conflictividad laboral existente en las zonas más industrializadas del país o con la democracia europea, descubrieron a sus paisanos la nueva realidad con la que habían entrado en contacto, acelerando el proceso de democratización en el mundo rural ${ }^{27}$. Uno de aquellos emigrantes politizados en su lugar de destino que actuó como vanguardia entre sus vecinos del agro fue un joven de 21 años oriundo de Andújar (Jaén) que se había marchado a trabajar al norte a comienzos de los sesenta. En una epístola enviada a la emisora comunista Radio España Independiente aseguraba que el único medio para abrir los ojos que tenían los jóvenes de su pueblo natal, en el que aseguraba que las condiciones de vida de sus habitantes eran las propias de la era feuda-

23. AHPCE, REI, 175/4, Granada, 01/07/1963.

24. INE, Censo agrario de 1962. «Explotaciones agrarias clasificadas según la superficie total de sus tierras y Distribución de la superficie según el régimen de tenencia»; CARRIÓN (1932: 264).

25. Archivo Municipal de Teba (AMTB), 82, 83 y 84, Padrón municipal de habitantes, 1951-1973.

26. Testimonio de Juan Jiménez Rodríguez (1937), entrevistado en Teba (Málaga) el 09/06/2016.

27. Sobre la contribución de los emigrantes retornados a la democratización, véanse PRADA (1997), LATORRE (2006: 88-91) y FUERTES (2015: 73-75). 
lista [sic], pasaba por la emigración. Además, hacía un llamamiento a la juventud para que nos levantemos juntos y hagamos toda clase de protestas contra esta vida que nos impone la dictadura de Franco. Como él mismo explicaba, cuando regresaba a su pueblo a pasar las vacaciones raro era el día que no venían a buscarme para hablar de política, de las cosas de España y, sobre todo, de su afán por saber más y más ${ }^{28}$.

Muchos de quienes emigraron al extranjero tuvieron sus primeras experiencias en huelgas y manifestaciones, conocieron de primera mano la sindicación libre y entraron en contacto con los opositores antifranquistas en el exilio. Cuando regresaban al pueblo, lo hacían con la maleta cargada no solo de ahorros, sino también de nuevas ideas prodemocráticas e incluso de propaganda subversiva. El vecino de Teba Juan Jiménez, que entre 1965 y 1968 marchó temporalmente a Francia para trabajar en la remolacha, estuvo a punto de cruzar la frontera con folletos de contenido revolucionario en el equipaje. Según su testimonio, los refugiados españoles lo tenían ya conquistado para que pasara una maleta de octavillas con el martillo y la hoz al regresar a casa tras la campaña agrícola. Lo animaron diciéndole que eso se pasa fácil y le dieron las instrucciones pertinentes: una vez pasado el mostrador, habría uno que hará una seña con un pañuelo y a ese es al que se lo tienes que entregar. Eso lo vas arrastrando y si a un caso, pues [dices] «la maleta no es mía». La tarde de la víspera acudió a recogerla y al abrirla pudo comprobar que contenía unos taquitos bien puestecitos de propaganda contra el régimen español. Pero en el último momento Juan fue consciente del alto riesgo en que incurriría y desistió de llevar a efecto la peligrosa operación ${ }^{29}$.

Otros muchos trabajadores de la mina y del campo se resistieron a abandonar sus hogares y optaron por permanecer en el pueblo, donde emprendieron una incansable lucha por la mejora de sus condiciones laborales. Y es que, aunque la disminución de la mano de obra disponible debido a la emigración se tradujo en un aumento de los salarios respecto de los jornales de miseria de posguerra, las relaciones laborales -marcadas por el corporativismo nacionalsindicalista- continuaron estando caracterizadas por la precariedad, la inseguridad y los abusos de la patronal. Las reivindicaciones estuvieron fundamentalmente dirigidas al incremento de la remuneración y a la reducción de la jornada y, aunque aparentemente resultaban de índole exclusivamente económica, tenían en realidad un trasfondo político. Estos obreros entendieron que su aspiración de mejorar las duras condiciones laborales que padecían no podría verse satisfecha bajo el régimen dictatorial franquista, sino que era necesaria la implantación de un sistema político democrático. Al exponer sus reivindicaciones político-laborales se instruyeron en el arte de la

28. AHPCE, REI, 191a/6, Jaén, 20/01/1966.

29. Testimonio de Juan Jiménez Rodríguez (1937), entrevistado en Teba (Málaga) el 09/06/2016. 
protesta y se familiarizaron con los hábitos de ciudadanía, por lo que el conflicto contribuyó a su politización, los alejó de la dictadura y los aproximó a la democracia. La articulación de quejas colectivas contra los despidos improcedentes, los bajos salarios, las largas jornadas laborales, la inseguridad en el puesto de trabajo u otros abusos de la patronal constituyó un primer ensayo de las prácticas democráticas ${ }^{30}$.

En las zonas rurales del sudeste andaluz los primeros conflictos colectivos de entidad tuvieron lugar a partir de finales de los cincuenta y comienzos de los sesenta. Entre aquellas primeras protestas laborales en la provincia de Granada estuvieron los paros de jornaleros de Moclín, Tózar, Olivares y Tiena en abril de 1957 y mayo de 1959; los conflictos surgidos entre los cortadores de caña de azúcar y las empresas azucareras en las localidades costeras de Motril, Salobreña y Almuñécar entre 1958 y 1963; o la huelga de los mineros de Alquife de $1962^{31}$.

Poco después del estallido de aquel conflicto minero en Granada se declaraba una nueva huelga en las minas de La Carlota, en Linares (Jaén). La protesta nacía del descontento de los trabajadores ante las reticencias de las empresas mineras a la hora de formalizar el aumento salarial de 35 pesetas acordado en noviembre de 1962 tras las gestiones realizadas por los delegados sindicales. Ante esta situación, el 31 de diciembre los mineros de la empresa La Cruz se negaron a iniciar los trabajos. Según un remitente que escribió a La Pirenaica narrando los hechos, inmediatamente hizo acto de presencia el director. Con un reloj en la mano, como si estuviera arbitrando un partido de fútbol, amenazó a los trabajadores en los siguientes términos: un cuarto de hora os doy para que lo penséis, o empezáis a trabajar o precinto el pozo. Al comenzar la cuenta atrás en voz alta los mineros respondieron: puede guardarse los minutos, el reloj y el pozo, no trabajamos mientras no se nos abone hasta el último céntimo. Según este testimonio, poco después se personaban en la mina un capitán de la Guardia Civil y un sargento acompañados de numerosos guardias, así como el gobernador civil con varios jerarcas sindicales de la provincia. Tras unos instantes de tensión, se acordó el nombramiento de una comisión de mineros, que finalmente logró que la empresa se comprometiese a pagar todo lo atrasado antes del 14 de enero ${ }^{32}$.

30. Sobre la politización campesina a partir de demandas como la percepción de unos precios agrarios más remuneradores, véase SABIO (2006: 78-90). Encontramos un ejemplo en el rural gallego, donde la protesta contra el pago de la cuota de la Seguridad Social Agraria o cota empresarial se vinculó a la lucha por la democracia (DíAz GEADA \& CABANA, 2013: 41-42).

31. ORTEGa (2003: 226, 287, 303).

32. AHPCE, REI, 175/6, Jaén, 09/01/1963. 
En los últimos años de la dictadura afloraron también episodios conflictivos en sindicatos como el del metal o el del olivo. En 1973 estallaron hasta once conflictos colectivos en diversas empresas de la provincia de Jaén que supusieron la pérdida de un total de 5.883 horas de trabajo. Una de ellas fue la metalúrgica Esteban Morales, de Mancha Real, donde los obreros realizaron dos paros en los que perdieron hasta 188 horas, en una acción que buscaba solidarizarse con un compañero sancionado injustamente. Otras empresas jiennenses afectadas por la conflictividad laboral de aquel año fueron las cooperativas aceiteras del Perpetuo Socorro, en Pegalajar, y la de San Ginés, en Sabiote, donde los trabajadores decretaron un paro y disminuyeron deliberadamente el rendimiento, respectivamente, para reivindicar mejoras salariales ${ }^{33}$.

Aquel año tuvieron lugar también conflictos laborales en el incipiente sector servicios de aquellos pueblos andaluces en los que más se había dejado sentir el boom turístico desde los sesenta. Fue el caso de Marbella, un municipio malagueño de la costa del Sol donde en 1973 estalló una protesta femenina en la empresa hotelera Skol. El conflicto sobrevino cuando la sección de personal de las camareras de piso decretó un paro de un día como queja ante el incumplimiento de las promesas salariales hechas por el hotel, y se resolvió rápidamente cuando las mujeres vieron satisfechas sus reivindicaciones económicas ${ }^{34}$.

También en el sector agrario, que en 1960 representaba el 57,2\% de la población activa en Andalucía oriental ${ }^{35}$, se dieron numerosos conflictos laborales a consecuencia de reivindicaciones como la reducción de la jornada de trabajo o las mejoras salariales. En la articulación de la protesta los trabajadores adquirían conciencia del riesgo que entrañaba hacer estas peticiones en el marco de una dictadura y de la necesidad de un régimen democrático que actuase con justicia y garantizase sus derechos laborales. Esta vinculación aparece clara en lo sucedido en Torreperogil (Jaén) en vísperas de la campaña de recolección de aceituna de 1963. Según relató un remitente a La Pirenaica, por aquellas fechas habían aparecido en el pueblo varios carteles en los que se pedía a la vez el aumento de salarios y la amnistía para los presos y exiliados políticos, y se concluía con un ¡Fuera Franco!. La contundencia con que actuaron las fuerzas del orden, que detuvieron e interrogaron a cuatro obreros por su supuesta implicación en el suceso, llevó a este vecino a preguntarse: ¿Cómo quieren que el pueblo les quiera? ${ }^{36}$.

33. Archivo General de la Administración (AGA), Memorias gobiernos civiles (Jaén), 32/11438. "Aspecto social», 1973.

34. AGA, Memorias gobiernos civiles (Málaga), 32/11439, 1973.

35. INE, Censo de 1960. «Población activa por grupos profesionales».

36. AHPCE, REI, 175/6, Jaén, 12/04/1963. 
Aquel año los obreros de Guadahortuna (Granada) decretaron un paro de protesta contra el incumplimiento por parte de los patronos de las bases de trabajo, que estipulaban un jornal mínimo de 125 pesetas ${ }^{37}$. Por las mismas fechas, otro trabajador de la provincia de Granada explicaba en su carta a Radio España Independiente que los obreros agrícolas, poco dispuestos a ser el cántaro mocho de la desastrosa política agraria del franquismo, iban a negarse a realizar las faenas de siega estivales por menos de 160 pesetas. Según su testimonio, aquella cantidad ni siquiera alcanzaría para pagar nuestras trampas continuas durante el invierno. El hombre culpaba de su tremenda miseria [al] régimen dictatorial fascista del general Franco y proponía dar la batalla de los salarios [para] vender más caro la única mercancía que poseemos, la fuerza de nuestro trabajo. Poco después, este trabajador relataba en una nueva epístola cómo unos treinta obreros del pueblo de Moraleda de Zafayona, que trabajan en la vega en el arreglo de acequias, se habían declarado en huelga para reivindicar un aumento salarial. Según su relato, los trabajadores agrícolas granadinos se mostraban cada vez más combativos y con un alto espíritu de clase y de solidaridad que había hecho fracasar los intentos de los contratistas para reclutar esquiroles en algunos pueblos cercanos donde se han producido los paros ${ }^{38}$.

Una de las estrategias de lucha de los trabajadores más novedosa en ese periodo fue el entrismo, a partir del cual acabarían naciendo las Comisiones Obreras (CC. OO.). La clase obrera instrumentalizó astutamente las elecciones sindicales franquistas, que habían comenzado a celebrarse en 1944 y que para comienzos de los sesenta estaban ya altamente desvirtuadas, para infiltrarse en las organizaciones sindicales y tratar de mejorar sus condiciones laborales. En este sentido, las elecciones sindicales de 1966 supusieron un salto cualitativo para penetrar en el sindicato vertical que, en el mundo rural, estaba representado por las Hermandades Sindicales de Labradores y Ganaderos (HSLG). Aunque se trataba de una estrategia de complicada ejecución, ya que requería de una participación colectiva y de una organización considerable, además de entrañar un elevado riesgo, resultaba altamente efectiva ${ }^{39}$. Así debió creerlo el jornalero de la comarca de Ronda (Málaga) que, en 1966, trató de preparar a los obreros agrícolas para las elecciones de otoño distribuyendo ejemplares de Mundo Obrero y La voz del campo. El plan pasaba por presentar una lista de candidatos propios y conseguir que fuera masivamente votada. Sin embargo, los esfuerzos resultaron en vano, pues los obreros de los pueblos de la zona no acu-

37. AHPCE, REI, 175/4, Granada, 29/07/63.

38. AHPCE, REI, 175/4, Granada, 26/05/1963 y 01/07/1963.

39. Sobre las CC. OO. en la provincia de Jaén, véase MARTínez López y CRUZ (2003). Algunas notas sobre el entrismo en la provincia de Granada, en ORTEGA (2003: 310). La infiltración de algún sujeto de filiación izquierdista en la HSLG pudo tornar el sindicato atractivo para los trabajadores (ORTIZ, 1992: 169-175; PÉREZ, 2017: 95-96). 
dieron a la cita electoral. El promotor de esta acción atribuía el fracaso al miedo que el pueblo seguía sintiendo hacia el verdugo, que era más grande que los deseos de libertad, $\mathrm{y}$ se mostraba convencido de que si los obreros hubiesen hecho las cosas como las debían de haber hecho, nosotros nos hacemos de los sindicatos y la Hermandad de Labradores y Ganaderos ${ }^{40}$.

Entre las nuevas acciones de protesta puestas en marcha por los trabajadores agrarios andaluces durante el tardofranquismo estuvieron también las tractoradas y las guerras agrarias, que acabaron ligándose a la lucha por la democracia ${ }^{41}$. Una de las más sonadas en Andalucía oriental fue la conocida como guerra de las lechugas, que estalló en 1977 en la provincia de Granada y se extendió poco después a Málaga. Unas mil familias vivían de este cultivo en los pueblos granadinos de Zafarraya, Ventas de Zafarraya y Almendral, donde se producían entre 25 y 30 millones de lechugas que se colocaban fundamentalmente en la provincia de Málaga y, en menor medida, en Córdoba, Jaén y Granada. El conflicto venía motivado por el escaso margen de beneficio para el agricultor, que tan solo percibía 1,50 pesetas de las 12 que podía alcanzar la unidad en el mercado. Para acabar con los abusos de los intermediarios, los cultivadores organizaron varias reuniones asamblearias en las que acordaron no vender la lechuga a menos de 4 pesetas. Además, constituyeron una comisión que solicitó autorización al gobernador civil, al alcalde y al delegado provincial del Ministerio de Agricultura para colocar directamente su producto. El día 21 de julio ocho camiones cargados con hasta cuarenta mil lechugas procedentes de estas localidades granadinas partieron rumbo a Málaga luciendo pancartas reivindicativas en las que podían leerse eslóganes de cariz político como Los intermediarios imponen aún su dictadura, Precios justos para el labrador o fusticia para las lechugas $^{42}$.

Por último, una de las cuestiones que más incidió en la transformación de la cultura política de los trabajadores del campo fue la negociación colectiva, para lo cual utilizaron instrumentalmente la ley de convenios colectivos aprobada por el régimen de Franco el 24 de abril de 1958 (BOE de 25 de abril de 1958) ${ }^{43}$. En el transcurso de las reuniones y discusiones en el marco de la HSLG, los obreros agrícolas se impregnaban de valores prodemocráticos. Al tiempo, el sindicato vertical franquista se revelaba como espa-

40. AHPCE, REI, 191a/7, Málaga, 1966.

41. Herrera (2011: 168); Gómez Oliver (2007: 151). Sobre estas «guerras» en el rural gallego, véase CABANA et al. (2013).

42. G. Fausto, «Se extiende la guerra de la lechuga», $A B C$ Sevilla, 22/07/1977, p. 15.

43. Esta movilización estaría en la base de la construcción de un nuevo marco de relaciones laborales durante la transición (MOYANO, 1984: 45-48.) 
cio de resocialización política en el agro y como cantera de la que saldrían muchos de los primeros cargos municipales electos ${ }^{44}$. Además, con el objetivo de presionar a los patronos para obtener unas condiciones laborales más ventajosas, los trabajadores combinaron la negociación colectiva con acciones de protesta político-económica como la huelga 45 .

Apenas un mes después de aprobarse la ley estalló un importante conflicto en la localidad malagueña de Teba, que contaba con una larga tradición de lucha obrera a sus espaldas que se remontaba a los años de la Segunda República. La memoria, ya fuera de primera mano o transmitida, de luchas como la de 1934, cuando el pueblo se convirtió en el único municipio (junto a Prado del Rey, en Cádiz) en el que triunfó la revolución de octubre, seguía estando muy presente entre los trabajadores de la localidad ${ }^{46}$. Los acontecimientos se precipitaron en una fecha sorprendentemente temprana, como mayo de 1958, un momento en el que las salidas de emigrantes del pueblo todavía no habían alcanzado cotas demasiado importantes y los jornaleros más comprometidos seguían residiendo en la localidad. Aquel año, al comenzar las faenas de siega, los productores infringieron la reglamentación de trabajo y se negaron por primera vez a trabajar durante más de seis horas diarias. Daba inicio un conflicto que se iba a prolongar durante varios lustros y que iba a suponer una importante toma de conciencia por parte de los trabajadores tebeños.

Según reconocían los representantes sindicales de los patronos, en aquellos días la jornada laboral de seis horas se llegó a generalizar en la localidad por imposición de los propios obreros. Los intentos de los empresarios de contratar en la plaza del pueblo a trabajadores por una jornada de siete horas para las labores de siega y de ocho horas para las restantes faenas resultaban en vano ante la negativa rotunda y unánime de los productores, que repetían que solamente trabajaban seis horas. El día 24 de mayo de aquel año de 1958 varios obreros que habían sido contratados para una jornada de siete horas en una finca del pueblo incumplieron lo pactado al abandonar el tajo transcurridas seis horas. Durante los días 25 y 26 el paro había sido total en todas las faenas, por lo que realmente $y$ de hecho se ha llegado a una huelga general ${ }^{47}$.

44. Sobre la adaptación de las viejas élites sindicales franquistas al nuevo contexto democrático en la Galicia rural, véase FERRÁndeZ PÉREZ y LANERo (2017).

45. Barranquero (1997); Ortega (2004); Juliá (2000: 105); Soto (1992: 150-152).

46. Morales (2004: 92-94), Brenes, FernándeZ y Fuentes (2019).

47. Archivo Cámaras Agrarias de Teba (ACAT), Actas de la HSLG: 1948-1958, sin signatura. «Sesión extraordinaria de la Sección Económica de la HSLG de Teba», 26/05/1958. 
La protesta colectiva continuó en 1959 con los trabajadores de Teba dando de mano en el tajo al cabo de las seis horas, lo que suscitó las quejas de los propietarios, que los acusaban de incumplir la reglamentación ${ }^{48}$. La lucha seguía viva a comienzos de 1960 con sucesos como el acaecido cuando el labrador A. E. F. comunicó a los operarios de su finca que debían trabajar las siete horas que fijaba el reglamento, por las que les aumentaría la parte proporcional del sueldo contratado. Ante aquel anuncio, todos respondieron con unanimidad que por ningún dinero más darían las siete horas de trabajo ${ }^{49}$. Durante el conflicto los obreros llegaron incluso a organizar un viaje a Madrid para reunirse con el ministro de Trabajo Fermín Sanz-Orrio y exponerle la situación ${ }^{50}$.

Uno de los protagonistas de aquellos acontecimientos fue el ya presentado Juan Jiménez, que durante el conflicto hubo de enfrentarse a la amenaza de la represión y al miedo de sus familiares por su implicación política, percibida en términos negativos por la generación que había vivido la contienda. En el transcurso de la protesta, tanto Juan como sus compañeros aprendieron a defender sus derechos laborales y a exponer argumentos favorables a su petición de trabajar seis horas, que estimaban justa. Además, lograron hacer oír su voz en el marco de una dictadura, se instruyeron en el arte de la reivindicación político-laboral y se familiarizaron con la práctica de hacer plaza como medio de lucha. El conflicto continúa estando muy presente en la memoria colectiva del pueblo, como muestra el testimonio de este tebeño:

La patronal quería siete horas, los trabajadores seis.Y así se estuvo aqui un mes. Pegaron un chivatazo, "que el pueblo se habia levantado contra el Gobierno».Y yo no sé de dónde vinieron tantos civiles, que había civiles por la Camorra, en lo alto de El Grupo, en el castillo, aqui en la sierra del Carmen. El pueblo todo rodeado de guardias civiles.Y yo era chico cuando el revoleo ese, como mi madre estaba ya tan... de mi padre, pues me sujetaba. No quería que fuera todas las mañanas a «hacer plaza», a defender las seis horas. Me sujetaba y yo respetaba a mi madre. Pero luego rejuntamos para que fueran a hablar con el ministro de Trabajo, que yo di 10 ptas. para el tren, porque fueron dos delegados obreros (El Rubito y fonena), para el tren, para la comida y eso. Que, por cierto, el ministro de Trabajo dijo que qué pasaba en Teba, que cómo se habian levantado. «No, no mire usted, aqui no se ha levantado nadie, nada más que la patronal quiere siete horas y nosotros queremos seis, porque con seis horas está bien».Y entonces dijo: «bueno, sí, está aprobado».Y entonces: «No,

48. ACAT, Minutas de Cabildo de 1957-1964, sin signatura. "Actas de reuniones de la HSLG».

49. ACAT, Correspondencia entrada 1960-1, sin signatura, 03/02/1960.

50. Algunas notas sobre las visitas de comisiones de trabajadores al ministro de Trabajo, en BERNAL (2010: 420-422). 
nos lo tiene que dar por escrito para presentarlo nosotros al sindicato, para que nos escuche y vea que usted ha aprobado las seis horas" ${ }^{51}$.

\section{LA PARROQUIAY EL SALÓN PARROQUIAL: LA CONFLICTIVIDAD EN EL ÁMBITO ECLESIÁSTICO}

Que en España hay mucha hambre de dinero, libertad y pan [...] que hay que protestar y no tener miedo, que no pasa nada $a^{52}$.

Desde los días de la Cruzada de Liberación, la Iglesia y el Estado franquista habían quedado unidos por la ideología del nacionalcatolicismo. Sin embargo, a partir de la década de los sesenta y, especialmente, a raíz de la recepción en España de las doctrinas emanadas del Concilio Vaticano II, proliferaron en el seno de la institución eclesiástica posturas críticas con el régimen, hasta ese momento prácticamente inexistentes dentro del catolicismo español. El «despegue» de parte de la Iglesia respecto de la dictadura puso fin a décadas de legitimación ideológica del franquismo ${ }^{53}$. Paradójicamente la Iglesia, que había sido durante los años treinta una de las principales responsables del fracaso del proyecto democratizador de la Segunda República, se convirtió a partir de los años sesenta en uno de los más importantes adalides del cambio político ${ }^{54}$.

A la hora de valorar el alcance del desenganche de la Iglesia respecto de la dictadura, autores como Antonio Cazorla han defendido que este nunca fue completo y que los disidentes católicos fueron una pequeña minoría hasta finales de los años sesenta y aún después. El grueso de los miembros de instituciones y organizaciones católicas, incluyendo a la mayoría del clero, apoyó a Franco hasta el final. Sin embargo, investigadores como Laura Serrano, que ha estudiado el caso de la diócesis de Valladolid, otorgan a la Iglesia un rol fundamental en el advenimiento de la democracia. En esta misma línea se encuentran los trabajos de Pablo López Chaves, que sitúan en la década de los cincuenta, antes del Concilio Vaticano II, el comienzo del desvío de parte de la intelectualidad católica respecto del nacionalcatolicismo y la precoz apuesta de la Iglesia por la democratización. Por su parte, Feliciano Montero ha defendido una vía intermedia al hablar de claro impulso y

51. Testimonio de Juan Jiménez Rodríguez (1937), entrevistado en Teba (Málaga) el 09/06/2016.

52. Sermón pronunciado por el cura en la iglesia de Cojáyar (Granada) en 1968. AGA, Dossier actividades clero diócesis Granada, 42/09004, 2, 23/08/1968.

53. Montero (1994: 233-234). Sobre la crisis Iglesia-Estado a raíz del Concilio Vaticano II, véase De Carli (2011).

54. Juliá (1990). 
apoyo a la reforma política en la dirección democrática ${ }^{55}$. Este artículo suscribe esta última interpretación y trata de demostrar que durante el tardofranquismo un importante sector de la Iglesia rural de base apostó por la democratización.

En este viraje ideológico los párrocos rurales, que durante el primer franquismo habían constituido uno de los principales baluartes del poder local en los pueblos, pasaron de ser los mejores aliados de la dictadura a criticarla abiertamente. Pertenecientes a una nueva generación que no había vivido la Guerra Civil, tomaron conciencia de la problemática social que los circundaba y se sintieron atraídos por ideologías próximas al marxismo ${ }^{56}$. Según Díaz-Salazar, los tres principios que configuraban la cultura política de estos católicos de izquierdas eran la prioridad de los pobres, la centralidad de la persona frente al capital y al Estado, y la socialización de la economía desde la perspectiva de la comunión de bienes. Siguiendo la máxima del ver, juzgar y actuar propia de la revisión de vida, se despegaron de la dictadura, convirtiéndose en uno de los principales grupos de oposición y pasando a remar en la dirección que conducía a la democra$\mathrm{cia}^{57}$.

Desde finales de los años sesenta y principios de los setenta comenzaron a llegar a los pueblos de las provincias altoandaluzas sacerdotes «díscolos» que llevaron hasta el mundo rural un nuevo espíritu de renovación. En 1972 el gobernador civil de Almería se refería a la labor que venían desarrollando en la provincia algunos sacerdotes de modernas tendencias y línea social-católica ${ }^{58}$. En 1974 su homónimo en Málaga aludía a la proliferación de sacerdotes contestatarios en pueblos como Antequera o Archidona que habían adoptado una actitud francamente hostil hacia el régimen ${ }^{59}$. Aquel mismo año la máxima autoridad civil de la provincia de Granada reconocía que el número de sacerdotes plenamente identificados con el régimen era escaso, mientras que eran numerosos los que se sienten proclives a la apertura y al reconocimiento de la plenitud de los derechos y libertades, cuyo pensamiento se inclinaba hacia la postura socializante. El gobernador insistía en que la actuación de los sacerdotes obreros y del clero postconciliar resultaba importante y comenzaba a dejarse sentir, y cifraba la proporción entre clero postconciliar y

55. Cazorla (2016: 235, 240); SERrano (2006); López Chaves (2016: 229-236); MonTero (1994: 230-231, 236).

56. Corrales (2008); Berzal (2013). Sobre la importancia que para estos religiosos tenía la cuestión social, véase HERMET (1985: 262-264).

57. Díaz-SAlazAr (2005: 107). También sobre la cultura política de estos católicos de izquierdas, véase MONTERO (2009: 212-219).

58. AGA, 52/00473, Memorias gobiernos civiles (Almería), 1972.

59. AGA, 32/11445, Memorias gobiernos civiles (Jaén y Málaga), 1974. 
preconciliar en la provincia en un $54 \%$ de línea avanzada, un $38 \%$ ortodoxo, un $6 \%$ progresista y un $2 \%$ inmovilista $^{60}$.

Durante el tardofranquismo los párrocos seguían manteniendo un importante ascendiente sobre los habitantes del mundo rural, especialmente sobre las mujeres, que constituían el grueso de la feligresía. Como muestra un informe elaborado en 1970, según el cual el cumplimiento dominical en Andalucía oriental rondaba el 74\%, la asistencia a los servicios religiosos seguía siendo muy significativa ${ }^{61}$. No obstante, esta cifra parece exagerada, pues aunque seguía siendo elevada, había entrado en una fase de decrecimiento. Hacia 1974 el número de asistentes a la misa de los domingos en la provincia de Granada se calculaba en un $40 \%$ para los habitantes de la capital y en un $20 \%$ para los moradores del agro. Las autoridades achacaban la disminución de la práctica religiosa a la progresiva materialización de las nuevas generaciones ${ }^{62}$.

A su llegada al pueblo los curas del sector «avanzado» del clero alteraban la cotidianeidad rural con la puesta en marcha de actividades rupturistas y con la difusión de mensajes subversivos que suponían una pequeña revolución a escala local. Imbuidos del espíritu postconciliar y sensibilizados con la cuestión social, introdujeron nuevos lenguajes y experiencias alejados de los adoptados por los párrocos tradicionales que hasta entonces habían paseado sus sotanas por las localidades españolas. Los religiosos disidentes renegaron de la ideología del nacionalcatolicismo, apostaron por la transmisión de pautas cívicas, y fomentaron el empoderamiento ciudadano y la cultura participativa. Las actuaciones de estos maestros de democracia estuvieron dirigidas en un doble sentido: la deconstrucción de muchos de los discursos franquistas aún vigentes y la construcción de otros nuevos de corte democrático ${ }^{63}$.

Su contribución a la democratización de la sociedad rural se concretó en la impartición de clases de religión metodológicamente novedosas y con contenidos críticos en las aulas de los centros de enseñanza primaria y media. Pero también en su oposición a la ritualidad y a la simbología del añejo nacionalcatolicismo, o en la elaboración y difusión de octavillas subversivas, en ocasiones en colaboración con otros movimientos apostólicos de renovación como la Juventud Obrera Católica (JOC) o la Hermandad Obrera de

60. AGA, 32/11444, Memorias gobiernos civiles (Granada), 1973, 1974.

61. FUNDACIÓN FOESSA (1970: 451). La asistencia mayoritaria a la misa dominical también es señalada en ACEVES (1971: 102).

62. AGA, 32/11444, Memorias gobiernos civiles (Granada), 1973 y 1974.

63. Algunos testimonios orales de párrocos progresistas sobre su contribución a la democratización en GROves et al. (2017b: 27-37). Véase también HERNÁNDEZ y ROMÁN (2019). 
Acción Católica (HOAC). Asimismo, su actividad prodemocrática se plasmó en la organización de charlas, reuniones y cursillos en el salón parroquial, el teleclub o la sacristía. Pero, sobre todo, halló su reflejo en la articulación de sermones contestatarios durante las homilías, en los que arremetían contra las injusticias sociales y las malas condiciones laborales de las clases humildes, o contra la violencia ejercida por el régimen sobre los opositores antifranquistas.

Uno de los mecanismos en manos de los sacerdotes postconciliares más eficaces a la hora de impulsar el proceso de democratización fue el repudio de la ritualidad y simbología características del nacionalcatolicismo. Párrocos como el de Albuñol (Granada) dejaron de pedir en las preces por el jefe del Estado ${ }^{64}$. Otros rechazaron la escenificación pomposa que rodeaba a los actos litúrgicos y apostaron por la austeridad ritual. Imbuido de estas ideas, el cura de Guarromán (Jaén) hizo campaña en 1973 contra la fiesta eucarística de Las Espigas, por cuyo motivo en pueblos como Jódar se habían pedido miles y miles de ptas. para una custodia mientras sus habitantes padecían el paro, la emigración, la escasez de vivienda o el analfabetismo ${ }^{65}$. Por su parte, el cura de Motril (Granada) había eliminado ciertos cultos e imágenes de su parroquia al concluir el Concilio Vaticano II.

Además, con la voluntad de minar el principio de jerarquía y la gestualidad deferente, durante la misa en honor a la Virgen Divina Pastora en octubre de 1968 este sacerdote se negó a que se formara estrado en el templo con sillones para las autoridades, como venía siendo tradición. Durante la homilía explicó que en la Iglesia son todos los feligreses iguales y no admitía deferencias para nadie. Probablemente inspirado en este ejemplo, otro cura de Motril decidió oponerse a la formación de estrado durante la Semana Santa, con lo que se expuso a las críticas de los sectores más conservadores, que estimaban que de esta forma los actos perdían la brillantez de antaño ${ }^{66}$. En esta misma línea, durante los festejos del Corpus Christi de 1970 el párroco de Trevélez (Granada) anunció que el palio podía ser llevado por todos los ciudadanos que quisieran hacerlo, y no como de costumbre en años anteriores que lo hacían los ricos y autoridades ${ }^{67}$. En el contexto de esa lucha que se estaba librando en el campo de lo simbólico, los párrocos progresistas restaron importancia a los ataques iconoclastas perpetrados contra los objetos sagrados. Así lo hizo el cura del pueblo granadino de Campotéjar al comentar que la propaganda franquista

64. AGA, 42/09004, 2, Dossier actividades clero diócesis Granada, Albuñol, 12/02/1968.

65. AGA, 42/09004, 2, Dossier actividades clero diócesis Jaén, Guarromán, 12/07/1973.

66. AGA, 42/09004, 2, Dossier actividades clero diócesis Granada, Motril, 25/10/1968 y 09/06/1970.

67. AGA, 42/09004, 2, Dossier actividades clero diócesis de Granada, Trevélez, 05/06/1970. 
había exagerado lo ocurrido en febrero de 1968 en la Universidad de Madrid, donde unos estudiantes arrojaron por la ventana el crucifijo de una de las aulas. En opinión de este religioso, no se trataba más que de una imagen del señor en madera o escayola, que mucha más importancia hay que darle al paro obrero existente y al despido masivo de estos de las fábricas ${ }^{68}$.

Los párrocos contestatarios se opusieron también a la celebración de algunas de las efemérides más destacadas del calendario festivo franquista. Así lo hizo el cura de Loja (Granada) en 1969, cuando rehusó oficiar los actos religiosos que venían celebrándose el 18 de agosto para conmemorar el día de la «liberación» de la localidad por parte de las tropas franquistas durante la guerra. El religioso argumentó que, debido al tiempo transcurrido, deberían desecharse dichos actos en evitación de recuerdos desagradables. Meses después este mismo párroco se negó a oficiar el funeral del 20 de noviembre por el alma de José Antonio Primo de Rivera que venía celebrándose cada año desde hacía tres décadas. Como consecuencia de su negativa, los actos conmemorativos de la muerte del fundador de Falange se vieron reducidos aquel año a la tradicional ofrenda floral ante la cruz de los Caídos. Los fastos del día de los Caídos fueron objeto de controversia en otras muchas localidades que contaban con un cura progresista, como Vélez de Benaudalla (Granada). Con motivo de los de 1970, el párroco de este pueblo se opuso tajantemente a rezar el responso ante la cruz de los Caídos, a leer la leyenda del testamento de José Antonio y a cantar el Cara al Sol. Aquel 20 de noviembre, mientras un grupo de adeptos se congregaba en las inmediaciones del templo, salió y cerró airadamente la puerta. También el cura de Jorairátar, una localidad ubicada en la comarca granadina de La Alpujarra en la que abundaban los párrocos de talante progresista, se negó rotundamente a colocar en la fachada de la iglesia una lápida en honor de los Caídos en la Cruzada de Liberación ${ }^{69}$.

Estos párrocos «alborotadores» también elaboraron e imprimieron clandestinamente octavillas y hojas parroquiales subversivas, que repartían entre los feligreses. A menudo esta propaganda recogía reivindicaciones sociales que buscaban mejorar las condiciones educativas, sanitarias o laborales de los hombres y mujeres de los pueblos andaluces. Fue el caso de la hoja escrita a multicopista en junio de 1969 por encargo de los sacerdotes de las localidades jiennenses de Chilluévar y El Molar, que fue distribuida entre el vecindario. En el escrito, que aludía al problema de la falta de escuelas y de material escolar, se instaba a tomar conciencia de este derecho y a exigir a las autoridades una infor-

68. AGA, 42/09004, 2, Dossier actividades clero diócesis Granada, 27/02/1968.

69. AGA, 42/09004, 2, Dossier actividades clero diócesis Granada, Loja, Vélez de Benaudalla y Jorairátar, 01/12/1969, 20/11/1970 y 10/05/1968, respectivamente. 
mación clara y precisa ${ }^{70}$. En una línea similar iban las hojas clandestinas sobre el Seguro Obligatorio de Enfermedad que en abril de 1971 entregaron los coadjutores de la parroquia de Loja (Granada) a los asistentes a una conferencia. También el tema de la creciente conflictividad laboral fue recogido en octavillas, como las repartidas en agosto de 1970 por varios monaguillos de Trevélez (Granada) a la salida de misa. En el escrito de siete páginas elaborado por el párroco se abordaban críticamente los recientes sucesos acaecidos en Granada, donde la huelga de los obreros de la construcción se había saldado con tres víctimas mortales fruto de la represión dictatorial ${ }^{71}$. En otras ocasiones las hojas parroquiales contenían propaganda política netamente antifranquista y prodemocrática. Así ocurrió con las repartidas el 15 de abril de 1973 durante la misa celebrada en la iglesia de Coín (Málaga), en las que podía leerse que las principales exigencias en esos momentos en España eran

reconocimiento de derechos y libertades fundamentales, civiles y politicas, derecho al trabajo, seguridad social, a la huelga, a la cultura, a las minorias étnicas y culturales; superación de la estructura injusta de la sociedad capitalista y de sus defectos; superación de la dialéctica amigos-enemigos y vencedores-vencidos para establecer auténtica igualdad socio-política ${ }^{72}$.

Otra vía empleada por los párrocos rurales para la transmisión de valores democráticos a las comunidades locales fueron las reuniones, charlas o cursillos celebrados en la sacristía o en el salón parroquial. Este fue el recurso empleado en 1965 por el cura de Escañuela (Jaén), que logró atraer a numerosos jóvenes al centro parroquial, donde acostumbraba a comentar la actualidad política. En una de las reuniones celebradas, por ejemplo, abordó críticamente el tema de los sindicatos y de la Magistratura de Trabajo ${ }^{73}$. Por su parte, el cura de Jorairátar (Granada) arremetió contra el régimen, los capitalistas y la Guardia Civil, a la que acusaba de no reportar ningún beneficio a la nación y de cobrar muy bien por aplastar a los obreros que trataban de defender sus derechos, durante la impartición de unos cursillos para jóvenes en septiembre de 1968. Movidos por este mismo impulso contestatario, llegaron a Montefrío en septiembre de 1970 tres seminaristas procedentes de Granada y Loja para hacer apostolado religioso entre los jóvenes y los campesinos del pueblo. Durante sus charlas, que se celebraron en cortijos y se prolongaron durante una semana, los animaron a dejar de sembrar las tierras de no ser que las auto-

70. AGA, 42/09004, 2, Dossier actividades clero diócesis Jaén, Chilluévar, 21/06/1969.

71. AGA, 42/09004, 2, Dossier actividades clero diócesis Granada, Loja y Trevélez, 21/04/1971 y 09/08/1970, respectivamente.

72. AGA, 42/09005, 2, Dossier actividades clero diócesis Málaga, Coín, 03/05/1973.

73. AGA, 42/09004, 2, Dossier actividades clero diócesis Jaén, Escañuela, 23/03/1965. 
ridades mejorasen sus condiciones de vida.Y no menos aleccionadora resultó la reunión celebrada el 2 de noviembre de 1970 en la sacristía de la iglesia de Nigüelas (Granada) después de la misa. En la charla, ofrecida por un matrimonio llevado por el cura, se pudo escuchar que si ayudarse unos a otros, repartir el trabajo y los bienes, vivir con la mejor igualdad y amarse unos a otros era comunismo, jviva el comunismo! ${ }^{74}$.

Muchos de estos clérigos rurales de talante progresista promovieron la instalación en el salón parroquial de un teleclub o local público en el que ver la televisión, con la pretensión de crear un espacio para el entretenimiento de la juventud y de celebrar reuniones en las que abordar asuntos políticos. Tales parecen haber sido las intenciones del cura de Nerva (Huelva) en marzo de 1968, cuando solicitó a la Delegación Provincial de Información y Turismo una subvención para adquirir el local y el material necesarios para la constitución de un teleclub. Las autoridades desestimaron el proyecto por considerar que el verdadero propósito del sacerdote era tener un local autorizado donde, con legalidad, celebrar reuniones sin previa autorización gubernativa y reservándose el derecho de admisión, evitando la entrada a personal que no interesase, y por sospechar que su auténtico objetivo era constituir las CC. OO. en la zona minera de La Naya-Riotinto. Por aquellas fechas, las autoridades reconocían que en varios pueblos de la provincia de Granada funcionaban teleclubs promovidos por sacerdotes progresistas, como los de Cacín, La Herradura, Nigüelas o Murtas ${ }^{75}$. También el teleclub de Vélez de Benaudalla (Granada), instalado en la casa parroquial, era empleado por el cura como espacio para la transmisión de pautas democratizadoras. En noviembre de 1970 reunió en este local a varios obreros de la JOC y la HOAC para tratar cuestiones como el funcionamiento de los sindicatos rusos, de los que se dijo que funcionan mejor que los españoles. Además, trajo a dos conferenciantes que animaron a los asistentes a reunirse y formarse para que el día que nos sea preciso podamos reclamar nuestros derechos, pues este pueblo quiere trabajar, pero que se le pague bien ${ }^{76}$.

Pero quizá la herramienta más efectiva y de la que más recurrentemente se valieron los párrocos contestatarios para arremeter contra la dictadura y defender la democracia fue el sermón. Pronunciado en el templo durante la homilía, fue dirigido fundamentalmente contra las injusticias sociales y laborales. Uno de los sucesos más frecuentemente comentados por estos curas durante la misa fue el de la huelga de los obreros de la construcción de Granada de 1970, que se tornó en tragedia el 21 de julio cuando tres mani-

74. AGA, 42/09004, 2, Dossier actividades clero diócesis de Granada, Nigüelas, 02/11/1970.

75. AGA, Ministerio de Información y Turismo, 42/9032,5. «Dossier con documentación referida a los teleclubs, 1966-76», 20/03/1968.

76. AGA, 42/09004, 2, Dossier actividades clero diócesis Granada, Vélez de Benaudalla, 09/12/1970. 
festantes cayeron muertos víctimas de la represión policial ${ }^{77}$. En los días sucesivos multitud de religiosos se pronunciaron sobre lo ocurrido criticando la violencia empleada por la Policía Armada. El coadjutor de la parroquia de Órgiva (Granada) se refirió a las víctimas en su homilía de las 20 horas, explicando que aunque hayan muerto en pecado mortal, habrían sido perdonados y estarán en el reino de los cielos, ya que solo pretendían el pan de sus hijos. El religioso añadió que, dado que en ningún sitio de España podría vivir ningún padre de familia con 120 ptas. jornal, la lucha quedaba totalmente justificada. También el párroco de Mecina Bombarón (Granada) se refirió a estos acontecimientos, afirmando que la peor parte la han llevado los más desgraciados, obreros y policías, mientras los verdaderos responsables estaban en el café o bañándose en la playa. Por su parte, el cura de Otívar (Granada) aseguró durante una misa que los obreros tenían toda la razón y que lo de Granada ha sido un crimen perfecto que quien lo hizo tiene que pagar ${ }^{78}$. El sacerdote al frente de las parroquias de Canillas de Aceituno y Salares (Málaga) también expresó durante la homilía su malestar con lo ocurrido ${ }^{79}$.Y en Macael (Almería) el párroco pronunció un sermón en el que definía la huelga como pacífica, legal y justa, por haberse hecho en defensa de los intereses del trabajador y como medio para aspirar a un salario que estuviera en consonancia con el actual coste de la vida ${ }^{80}$.

El otro gran conflicto laboral que más comentarios mereció en los sermones pronunciados por los religiosos "díscolos» fue el de la fábrica textil Intelhorce (Málaga) de septiembre de 1973. En aquellos días un grupo de obreros de la factoría, disconforme con el convenio colectivo recientemente firmado y que reclamaba mejoras salariales, permaneció varios días encerrado en la catedral hasta que finalmente fue desalojado por la fuerza. Como ocurriera con el de Granada de 1970, este suceso tuvo una gran repercusión y fue ampliamente comentado por los clérigos rurales progresistas de toda la provincia ${ }^{81}$. En el pueblo de Coín varios sacerdotes se refirieron durante la misa a lo acontecido en Málaga, explicando que el evangelio no puede callar las injusticias y tiene que unirse al débil y al desvalido. Además, pidieron en las preces para que los poderosos sepan mandar y no tengan que recurrir a la fuerza pública e hicieron una colecta destinada a los obreros de Intelhorce. Asimismo, arremetieron contra las autoridades que habían ordenado la actuación de la fuerza pública, contra el obispo de la diócesis que la había permitido y contra el Gobierno, tachándolos a todos de no cristianos. También el párroco de la localidad

\section{TUdELA (2010).}

78. AGA, 42/09004, 2, Dossier actividades clero diócesis Granada, Órgiva, Mecina Bombarón y Otívar, 02/08/1970, 03/08/1970 y 12/08/1970, respectivamente.

79. AGA, 42/09005, 2, Dossier actividades clero diócesis Málaga, Canillas de Aceituno, 14/08/1970.

80. AGA, 42/09001, Dossier actividades clero diócesis Almería, Macael, 01/09/1970.

81. BARRANQUERO (1998). 
malagueña de Villanueva de Algaidas se pronunció al respecto, explicando durante la homilía que los hechos habían sido lamentables, pues las reivindicaciones obreras obedecían a justicia y las fuerzas del orden estaban protegidas por un gobierno capitalista. El religioso concluyó que se había cometido una vez más una gran injusticia, expulsando a los pobres de la iglesia mientras los ricos eran admitidos con toda solemnidad ${ }^{82}$.

Otro de los grandes ejes temáticos en torno al que giraron los sermones contestatarios fue el de la represión dictatorial, que se agudizó durante los últimos años del franquismo. A ella hizo mención el cura de Jorairátar (Granada) durante una misa oficiada en agosto de 1968 cuando aseguró que la paz de que goza la nación es a costa del terror, que para sostener la paz no era necesaria tanta Guardia Civil ni Policía Armada o que no habia que llevarse bien con la Guardia Civil ${ }^{83}$. Encontramos otro ejemplo en Almería, donde el 16 de diciembre de 1970 el párroco jesuita a cargo de la iglesia del Sagrado Corazón de Jesús arremetió en la misa de las 11 contra el carácter violento de la dictadura, asegurando que las bayonetas no podrán sostener un régimen capitalista como el español $l^{84}$. Por esas mismas fechas, el párroco de Huélago (Granada) se refirió en una homilía al consejo de guerra que se estaba celebrando en Burgos contra dieciséis miembros de ETA acusados del asesinato de tres personas, implorando clemencia para los nueve condenados a muerte, cuyas penas fueron finalmente conmutadas. El clérigo se refirió también a la detención injustificada de varios estudiantes de la Facultad de Derecho de la Universidad de Granada ${ }^{85}$.Y en marzo de 1972 el sacerdote que decía misa en Castillo de Locubín (Jaén) lamentó que la fuerza pública disparara sus armas contra los obreros que defendían sus derechos en el Ferrol del Caudillo. Se refería a los sucesos que tuvieron lugar en este municipio coruñés entre los días 9 y 10, cuando las protestas laborales durante la negociación del convenio colectivo fueron duramente reprimidas ${ }^{86}$.

\section{CONCLUSIONES}

Durante el tardofranquismo y la transición, el mundo urbano no tuvo la exclusividad en lo referente a la movilización contra la dictadura de Franco, sino que también el ámbito rural se reveló altamente dinámico. Como evidencian los múltiples episodios contestatarios

82. AGA, 42/09005, 2, Dossier actividades clero diócesis Málaga, Coín, 15/09/1973 y 21/09/1973; y Villanueva de Algaidas, 09/09/1973.

83. AGA, 42/09004, 2, Dossier actividades clero diócesis Granada, Jorairátar, 23/08/1968.

84. AGA, 42/09001, Dossier actividades clero diócesis Almería, Almería, 19/12/1970.

85. AGA, 42/09004, 2, Dossier actividades clero diócesis Granada, Huélago, 12/12/1970.

86. AGA, 42/09004, 2, Dossier actividades clero diócesis Jaén, 22/01/1973. 
que tuvieron lugar durante este periodo en el campo altoandaluz -y que podrían extrapolarse a otros contextos espaciales de similares características socioeconómicas-, la contribución del agro al proceso de democratización fue muy considerable. En los últimos años del franquismo también en los pequeños núcleos de población de una región periférica como Andalucía la sociedad civil comenzaba a despertar de su largo y obligado letargo. Aunque las protestas en este ámbito no fueran tan numerosas ni espectaculares como las que estaban aconteciendo por las mismas fechas en las grandes urbes del país, el mundo rural estuvo interconectado con el urbano e incluso tuvo dinámicas de conflictividad y democratización autónomas.

Durante la década de los sesenta algunos espacios de socialización cotidiana como el lugar de trabajo, la iglesia o el salón parroquial se convirtieron en auténticas «escuelas de democracia». El tajo pasó a ser escenario de constantes conflictos entre patronos y jornaleros, que libraron una intensa lucha por la mejora de sus condiciones laborales que incluyó paros y huelgas. Por su parte, la parroquia se resignificó y se convirtió en uno de los espacios más dinámicos del mundo rural gracias a los sermones «subversivos» pronunciados por los curas contestatarios. También el salón parroquial adquirió un significado distinto del tradicional como espacio de diálogo y discusión de la juventud rural al acoger cursillos y reuniones de carácter progresista, o convertirse en sede del teleclub local. Todo ello fue posible gracias a la reafirmación de los habitantes del campo como seres políticos dispuestos a arremeter contra el régimen dictatorial y a apostar por su sustitución por otro de corte democrático.

A través de las acciones de protesta articuladas con el objetivo de mejorar sus vidas cotidianas, los vecinos y vecinas de los pueblos andaluces transformaban su cultura política en sentido democratizador. En sus múltiples y diversas luchas cotidianas aprendieron a debatir en un medio asambleario, rebatir argumentos contrarios, asumir posiciones discordantes, lidiar con la pluralidad o respetar decisiones consensuadas. Crecientemente familiarizados con valores democráticos, como la participación o la igualdad, tomaron conciencia de que sus reivindicaciones socioeconómicas tan solo podrían verse satisfechas bajo un sistema político que garantizase las libertades y derechos básicos.

\section{AGRADECIMIENTOS}

La autora forma parte del proyecto de investigación «Historia y memoria del hambre: sociedad, vida cotidiana, actitudes sociales y políticas de la dictadura franquista (19391959)». 
A la mejora de la versión final de este manuscrito han contribuido los comentarios realizados por los evaluadores anónimos de Historia Agraria.

\section{REFERENCIAS}

ABAD, C. \& NAREDo, J. M. (1997). Sobre la «modernización» de la agricultura española, (1940-1995): De la agricultura tradicional hacia la capitalización agraria y la dependencia asistencial. En C. Gómez Benito \& J. J. GonzÁlez Rodríguez (Eds.), Agricultura y sociedad en la España contemporánea (pp. 249-316). Madrid: Centro de Investigaciones Sociológicas.

Aceves, J. B. (1971). Cambio social en un pueblo de España. Barcelona: Barral.

BARRANQUERO, E. (1997). Negociación colectiva y conflictividad social en el sector textil: Málaga (1960-1970). Baetica: Estudios de Arte, Geografía e Historia, 19 (2), 233-243.

BARRANQUERo, E. (1998). Intelhorce: La fortaleza obrera entregada. Málaga: Universidad de Málaga.

BERNAL, F. (2010). El sindicalismo vertical: Burocracia, control laboral y representación de intereses en la España franquista (1936-1951). Madrid: Centro de Estudios Políticos y Constitucionales.

BERneCKer, W. L. (2007). The Change in Mentalities during the Late Franco Regime. En N. Townson (Ed.), Spain Transformed:The Late Franco Dictatorship, 1959-75 (pp. 67-84). New York: Palgrave Macmillan.

BERZAL, E. (2013). Clérigos y fieles ante el franquismo: La evolución de las actitudes políticas de los católicos durante el desarrollismo. En M. A. DEL ARCO, C. FuENTES, C. HERNÁNDEZ \& J. MARCo (Eds.), No solo miedo: Actitudes políticas y opinión popular bajo la dictadura franquista, 1936-1978 (pp. 177-194). Granada: Comares.

BRENES, M.I., FERNÁNDEZ, A.y FuENTES, J. (2019). El movimiento revolucionario de Teba. Octubre 1934. Antequera: Aratispi.

Cabana, A., Díaz Geada, A., Lanero, D., Taboada, A. \& Santidrián, V. M. (2013). Dinámicas políticas de la sociedad rural gallega: Entre la agonía de la dictadura y la implantación de la democracia (1970-1978). Historia del presente, (21), 123-144.

CARRIÓN, P. (1932). Los latifundios en España: Su importancia, origen, consecuencias y solución. Madrid: Gráficas Reunidas.

CAzorla, A. (2016). Miedo y progreso: Los españoles de a pie bajo el franquismo. Madrid: Alianza.

Cenarro, A. (2016). Género y ciudadanía en el franquismo. Ayer, (102), 13-21.

Cobo, F. \& ORTEGA, T. M. (2003). La protesta de sólo unos pocos: El débil y tardío surgimiento de la protesta laboral y la oposición democrática al régimen franquista en Andalucía oriental, 1951-1976. Historia Contemporánea, (26), 113-160. 
CoRrales, X. (2008). De la misa al tajo: La experiencia de los curas obreros. Valencia: Universitat de València.

De CARLI, R. (2011). La Iglesia ante la Transición democrática: ¿Confesionalidad tolerante o aconfesionalidad privilegiada? En M. Ortiz Heras \& D. A. GonZÁlez MADRID (Eds.), De la cruzada al desenganche: La Iglesia española entre el franquismo y la transición (pp. 77-101). Madrid: Sílex.

Díaz GeadA, A. \& Cabana, A. (2013). Más allá de un baile de papeletas: Acción colectiva, sindicalismo democrático y comportamiento electoral en la Galicia rural de la transición. En D. LANERo (Ed.), Por surcos y calles: Movilización social e identidades en Galicia y País Vasco (1968-1980) (pp. 33-65). Madrid: Catarata.

DíAz-SALAZAR, R. (2005). Religión y socialización política de los católicos en la lucha contra la dictadura. En J. M. CAstells, J. HuRTAdo \& J. M. MARgenat (Eds.), De la dictadura a la democracia: La acción de los cristianos en España (1939-1975) (pp. 101119). Bilbao: Desclée de Brouwer.

ELEY, G. (2003). Un mundo que ganar: Historia de la izquierda en Europa (1850-2000). Barcelona: Crítica.

Fernández Amador, M. \& Quirosa-Cheyrouze, R. (Coords.) (2017). Movimientos sociales e instituciones locales en la Transición: La lucha por la democracia en la Andalucía rural. Madrid: Catarata.

FERRÁndez PÉREZ, D. \& LANERo, D. (2017). Que veinte años no es nada...: Sobre la continuidad de los poderes locales en la Galicia rural entre franquismo y democracia (1973-1979). En D. A. González Madrid, M. Ortiz \& J. S. Pérez Garzón (Coords.), La Historia, lost in translation? Actas del XIII Congreso de la Asociación de Historia Contemporánea (pp. 1297-1310). Cuenca: Universidad de Castilla-La Mancha.

FERRER, C. (2014). Lluitadors quotidians: L'antifranquisme, el canvi polític i la construcció de la democràcia al Montsià (1972-1979). Lleida: Universitat de Lleida.

Foweraker, J. (1989). Making Democracy in Spain: Grass-Roots Struggle in the South, 1955-1975. Cambridge: Cambridge University Press.

Fuentes, M. C. (2012). El PCE y la construcción de la democracia en el campo andaluz durante los años 60: El «asamblearismo» campesino y jornalero y la difusión de valores pro-democráticos. En T. M. OrTEgA \& M. A. DEL ArCo (Eds.), Claves del mundo contemporáneo, debate e investigación: Actas del XI Congreso de la Asociación de Historia Contemporánea. Granada. Comares.

FuerTes, C. (2015).Vida cotidiana, educación y aprendizajes políticos de la sociedad española durante el franquismo. En M. PÉREZ LEDESMA \& I. SAZ (Eds.), Del franquismo a la democracia (1936-2013) (pp. 53-79). Madrid: Marcial Pons.

FUNDACIÓN FOESSA (1970). Informe sociológico sobre la situación social de España, 1970. Madrid: Euroamérica. 
GARCÍA BARBANCHO, A. (1975). Las migraciones interiores españolas en 1961-70. Madrid: Instituto de Estudios Económicos.

Gómez Oliver, M. (2007). ¿Y ahora qué?: La sociedad rural ante la Transición política.

En R. Quirosa-Cheyrouze (Coord.), Historia de la Transición en España: Los inicios del proceso democratizador (pp. 147-155). Madrid: Biblioteca Nueva.

GonzÁlez MAdrid, D. A. \& MARTín, O. J. (2009). In Movement: New Players in the Construction of Democracy in Spain, 1962-1977. Political Power and Social Theory, (20), 39-70.

Groves, T. et al. (2017a). Introduction. En T. Groves, N. Townson, I. Ofer \& A. HeRRERA (Eds.), Social Movements and the Spanish Transition: Building Citizenship in Parishes, Neighbourhoods, Schools and the Countryside (pp. 3-6). New York: Palgrave Mcmillan.

Groves, T. et al. (2017b). Catholicism and Citizenship under the Franco Dictatorhip. En T. Groves, N. Townson, I. Ofer \& A. Herrera (Eds.), Social Movements and the Spanish Transition: Building Citizenship in Parishes, Neighbourhoods, Schools and the Countryside (pp. 19-41). New York: Palgrave Mcmillan.

Hermet, G. (1985). Los católicos en la España franquista. I: Los actores del juego político. Madrid: Siglo XXI.

HERnÁNDEZ, C. \& RomÁn, G. (2019). Maestros de democracia con sotana: Los párrocos rurales y la construcción de la sociedad civil durante el tardofranquismo en la España meridional. Bulletin of Spanish Studies: Hispanic Studies and Research on Spain, Portugal and Latin America (en prensa).

Herrera, A. (2009). "Otra lectura de la Transición española es posible»: La democratización del mundo rural (1975-1982). Ayer, (74), 219-240.

HERRERA, A. (2011). Los procesos de democratización durante la Transición española: Viejos debates, nuevas propuestas. Historia Social, (71), 161-179.

Herrera, A., González de Molina, M. CruZ, S. \& Acosta, F. (2012). Propuesta para una reinterpretación de la historia de Andalucía: Recuperando la memoria democrática. Ayer, (85), 73-96.

Herrera, A. \& MArkoff, J. (2013). Democracia y mundo rural en España. Ayer, (89), 21-119.

Hormigo, T. (1977). Ciudadano y político. Boletín Informativo del Centro Cultural de Estepona, (14).

INGLEHART, R. \& WELZEL, C. (2009). Cómo conduce el desarrollo hacia la democracia: Lo que sabemos de la modernización. Foreign affairs: Latinoamérica, 9 (4), 117-130. JuLIÁ, S. (1990). Obreros y sacerdotes: Cultura democrática y movimientos sociales de oposición. En J. Tusell, A. Alted \& A. MATeos (Eds.), La oposición al régimen de Franco: Estado de la cuestión y metodología de la investigación (pp. 147-159). T. II. Madrid: Universidad Nacional de Educación a Distancia. 
Juliá, S. (2000). La Sociedad. En J. L. García Delgado (Ed.), Franquismo: El juicio de la historia (pp. 57-114). Madrid:Temas de Hoy.

LANERo, D. \& Míguez MACHo, A. (2013). ¿Lejos de la apatía?: Politización y movimientos sociales en la España rural del final del franquismo y la Transición (1968-1982): Un estado de la cuestión. En D. LANERo (Ed.), Por surcos y calles: Movilización social e identidades en Galicia y País Vasco (1968-1980) (pp. 7-31). Madrid: Catarata.

LATorre, M. (2006). Ciudadanos en democracia ajena: Aprendizajes políticos de la emigración de retorno española en Alemania durante el franquismo. Migraciones y Exilios, (7), 81-96,

López Chaves, P. (2016). Los intelectuales católicos en el franquismo: Las Conversaciones Católicas Internacionales de San Sebastián (1947-1959). Granada: Universidad de Granada.

MARKOFF, J. (2018). Olas de democracia: Movimientos sociales y cambio político. Granada: Comares.

MARTín, O. J. (2008). A tientas con la democracia: Movilización, actitudes y cambio en la provincia de Albacete, 1966-1977. Madrid: Catarata.

MARTín, O. J. (2016). «Un deprimido trozo de España»: La lucha por la democracia en una provincia subdesarrollada. En M. OrTIz Heras (Coord.), La Transición se hizo en los pueblos: El caso de la provincia de Albacete (pp. 179-200). Madrid: Biblioteca Nueva.

Martínez López, D. \& Cruz, S. (2003). Protesta obrera y sindicalismo en una región «idílica»: Historia de Comisiones Obreras en la provincia de faén. Jaén: Universidad de Jaén.

McAdam, D. (1988). Micromobilization Contexts and Recruitment to Activism. En B. Klandermans, H. Kriesi \& S. G. TARrow (Eds.), From Structure to Action: Comparing Social Movements Research Across Cultures (pp. 125-154). Greenwich: JAI Press.

Montero, F. (1994). La Iglesia y la transición. Ayer, (15), 233-241.

Montero, F. (2009). La Iglesia: De la colaboración a la disidencia (1956-1975). Madrid: Encuentro.

Morales, M. (Ed.) (2004). Ugetismo y socialismo en la España rural: Teba, un siglo de historia. Sevilla: UGT Andalucía.

MoYANO, E. (1984). Ideologías y sindicalismo agrario en la transición democrática. Agricultura y Sociedad, (31), 33-58.

Nicolás, M. E. (2007). La Transición se hizo en los pueblos: La vida política en Murcia (1968-1977). En R. Quirosa-Cheyrouze (Coord.), Historia de la Transición en España: Los inicios del proceso democratizador (pp. 251-267). Madrid: Biblioteca Nueva. Ortega, T. M. (2003). Del silencio a la protesta: Explotación, pobreza y conflictividad en una provincia andaluza, Granada 1936-1977. Granada: Universidad de Granada.

ORTEGA, T. M. (2004). Obreros y vecinos en el tardofranquismo y la transición política 
(1966-1977): Una «lucha» conjunta para un mismo fin. Espacio, tiempo y forma, (16), 351-370.

Ortiz, M. (1992). Las Hermandades de labradores en el franquismo, Albacete 1943-1977. Albacete: Instituto de Estudios Albacetenses.

OrTIZ, M. (2016). La Transición y sus variables interpretativas. En M. ORTIZ (Coord.), La Transición se hizo en los pueblos: El caso de la provincia de Albacete (pp. 19-44). Madrid: Biblioteca Nueva.

PÉrez, J. (2017). Las Hermandades de Labradores y Ganaderos en la provincia de Granada (1936-1951). Trabajo final de máster. Granada: Universidad de Granada (inédito).

PÉREZ Díaz,V. (1993). La primacía de la sociedad civil: El proceso de formación de la España democrática. Madrid: Alianza.

Polleta, F. (1999). Free Spaces in Collective action. Theory and Society, (28), 1-38.

PRADA, J. (1997). Conflicto y consenso: La emigración como instrumento de cambio ideológico y transformación social. En J. M. Trujillano \& J. M. GaGo (Coords.), Actas IV fornadas Historia y Fuentes Orales: Historia y memoria del franquismo (pp. 315338). Ávila: Fundacion Cultural Santa Teresa.

Radcliff, P. (2011). Making Democratic Citizens in Spain: Civil Society and the Popular Origins of the Transition, 1960-78. New York: Palgrave Macmillan.

SABIo, A. (2006). Cultivadores de democracia: Politización campesina y sindicalismo agrario progresista en España, 1970-1980. Historia Agraria, (38), 75-102.

SANZ, J. (2017). Presentación. En J. SANZ (Coord.), Las luchas por las libertades y la reconquista de la democracia en España (dossier). Nuestra Historia, (3), 11-17.

Serrano, L. (2006). Aportaciones de la Iglesia a la democracia desde la diócesis de Valladolid: 1959-1979. Salamanca: Universidad Pontificia de Salamanca.

Sevillano, F. (2000). Ecos de papel: La opinión de los españoles en la época de Franco. Madrid: Biblioteca Nueva.

Soto, A. (1992). Diversas interpretaciones sobre las causas y consecuencias de las huelgas en el Franquismo (1963-1975) (pp. 150-152). En Actas I Encuentro de Investigadores del Franquismo. Barcelona: Universidad Autónoma de Barcelona.

Tilly, C. (2010). Democracia. Madrid: Akal.

Tudela, E. (2010). Nuestro pan: La huelga del 70. Granada: Comares.

YsÀs, P. (2006). La crisis de la dictadura franquista. En C. Molinero (Ed.), La Transición, treinta años después: De la dictadura a la instauración y consolidación de la democracia (pp. 27-58). Barcelona: Península.

YsÀs, P. (2007). ¿Una sociedad pasiva?: Actitudes, activismo y conflictividad social en el franquismo tardío. Ayer, (68), 31-57.

Zambrana, J. F. (Coord.) (2002). Estadísticas históricas del siglo Xx en Andalucía. Sevilla: Instituto de Estadística de Andalucía. 